\title{
Modes of the $\mathrm{Na}$ Channel Blocking Action of Pilsicainide, a New Antiarrhythmic Agent, in Cardiac Cells
}

\author{
Yoshikazu Hattori and Norio Inomata* \\ Laboratory of Molecular Pharmacology, Suntory Institute for Biomedical Research, \\ Shimamoto-cho, Mishima-gun, Osaka 618, Japan
}

Received October 14,1991 Accepted December 24. 1991

\begin{abstract}
Using a whole cell clamp technique, the blockade of sodium currents $\left(\mathrm{I}_{\mathrm{Na}}\right)$ by pilsicainide, a new antiarrhythmic agent, applied either intracellularly or extracellularly, was studied in single myocytes isolated from guinea pig right ventricle. Pilsicainide applied extracellularly inhibited the peak amplitude of $\mathbf{I}_{\mathrm{Na}}$ in concentration- (from $10^{-5} \mathrm{M}$ to $10^{-4} \mathrm{M}$ ) and rate- (from $0.5 \mathrm{~Hz}$ to $3.0 \mathrm{~Hz}$ ) dependent manners. The onset rate of the blockade in $\mathrm{I}_{\mathrm{Na}}$ was almost constant, independent of frequency of stimulus, but higher at high concentration of pilsicainide. The time constant in the recovery phase from $\mathbf{I}_{\mathrm{Na}}$ inactivation remained almost constant (65 to 75 $\mathrm{msec}$ ) in the range of concentrations used. Similar results were obtained by intracellular application of $10^{-3} \mathrm{M}$ pilsicainide. Pilsicainide applied intracellularly inhibited $\mathrm{I}_{\mathrm{Na}}$ in a rate-dependent manner. The blocking potency of internally applied pilsicainide almost corresponded to that of external $10^{-5} \mathrm{M}$ pilsicainide. The onset rate of $\mathrm{I}_{\mathrm{Na}}$ inactivation (from $0.098 /$ pulse to $0.130 /$ pulse) and the recovery time constant $(77 \mathrm{msec}$ ) was similar to those of external $10^{-5} \mathrm{M}$ pilsicainide. These results suggest that pilsicainide, irrespective of intra- or extracellular application, shares a common binding site to block $\mathrm{I}_{\mathrm{Na}}$ in cardiac myocytes.
\end{abstract}

$\mathrm{Na}$ channel blocking action represents an important mode of action for antiarrhythmic agents. Antiarrhythmic agents of lidocaine derivatives are thought to block $\mathrm{Na}$ channels in charged and/or non-charged form at physiological $\mathrm{pH}$ (1). It is predicted that a charged molecule would block $\mathrm{Na}$ channels through a process different from that of a non-charged one. Non-charged molecules seem to reach their binding sites in the channel by dissolving in the lipid phase of the neuronal membrane $(1,2)$. In contrast, charged molecules reach their binding sites from the inner side of the

\footnotetext{
* To whom all correspondence should be addressed.
}

Na channels via a hydrophilic pathway $(2,3)$, which is available when the gates of the channels are open (3).

Recently, Carmeliet et al. (4) have reported that a local anesthetic, penticainide, which is positively charged at $\mathrm{pH} 7.4(\mathrm{pKa}=10.0)$, exerted a block of cardiac $\mathrm{Na}$ channels when it was applied to the outer side of the cardiac cell membrane, while no significant block was observed by application of the drug to the inner side of the S-DPI 201-106 (which is known to slow $\mathrm{Na}$ channel inactivation) treated cardiac cell membrane. On the other hand, these authors found that penticainide reduced $\mathrm{I}_{\mathrm{Na}}$ by acting from the outside as well as from the 
cytoplasmic side of the $\mathrm{Na}$ channels in untreated guinea pig ventricular myocytes (5). On the basis of these observations, they suggested that S-DPI 201-106 prohibited the binding of penticainide from the inside. Therefore, whether the charged molecule blocks Na channels by acting from the outside or from the inner side of the myocyte membrane, unlike its blocking effect in neurons, remains unclear.

In a recent study with a permanently charged lidocaine-derivative, QX-314, Alpert et al. (6) has shown that QX-314 blocked the $\mathrm{Na}$ current not only by its intracellular application, but also by its extracellular application in a single cardiac Purkinje fiber. QX-314 caused a first pulse block (diminution in peak $\mathbf{I}_{\mathrm{Na}}$ in the first depolarizing pulse) when applied to the inside, while it produced a use-dependent block when applied outside. Based on these findings, they have proposed the presence of a second binding site for local anesthetics in the $\mathrm{Na}$ channels of cardiac tissue, unlike noncardiac tissue.

Pilsicainide, $\quad N$-(2,6-dimethylphenyl)-8-pyrrolizidine-acetamide hydrochloride hemihydrate (SUN 1165), is a newly developed antiarrhythmic agent with $\mathrm{Na}$ channel-blocking action $(7-11)$. The compound is characterized by its highly basic pyrrolizidine ring structure $(12,13)$; and because of its high pKa (10.5), most of the pilsicainide molecules exist in the charged form at physiological $\mathrm{pH}$ (14). The aim of this study is to determine whether pilsicainide, a charged molecule, blocks Na channels from the inside and/or the outside of the cardiac cell membrane by using a whole cell clamp technique. The possible presence of a second binding site for pilsicainide was also investigated by analyzing the kinetics of its binding to and dissociation from the binding site.

\section{MATERIALS AND METHODS}

\section{Preparation}

Experiments were carried out on right ventricular cells of the guinea pig. The cells were dispersed by an enzymatic procedure similar to that reported previously (15). Male guinea pigs weighing $300-500 \mathrm{~g}$ were anesthetized with sodium pentobarbital $(30 \mathrm{mg} / \mathrm{kg})$ applied intraperitoneally. The aorta was cannulated, and the heart was excised and perfused through the aorta with Tyrode's solution ( $\mathrm{pH}$ 7.4) containing $136.5 \mathrm{mM} \mathrm{NaCl}, 5.4 \mathrm{mM} \mathrm{KCl}$, $1.8 \mathrm{mM} \quad \mathrm{CaCl}_{2}, \quad 0.53 \mathrm{mM} \quad \mathrm{MgCl}_{2}, \quad 0.33 \mathrm{mM}$ $\mathrm{NaH}_{2} \mathrm{PO}_{4}, 11.9 \mathrm{mM} \mathrm{NaHCO}, 5.5 \mathrm{mM}$ glucose and $5.0 \mathrm{mM}$ HEPES. The heart was then perfused with "nominal" $\mathrm{Ca}^{2+}$-free Tyrode's solution until the spontaneous contractions stopped. Thereafter, the heart was perfused with $\mathrm{Ca}^{2+}$-free Tyrode's solution containing $0.4 \mathrm{mg} / \mathrm{ml}$ collagenase (Sigma, Type 1) for about $45 \mathrm{~min}$ followed by wash-out with a high $\mathrm{K}^{+}$-storage solution containing $85 \mathrm{mM} \mathrm{KCl}$, $30 \mathrm{mM} \quad \mathrm{K}_{2} \mathrm{HPO}_{4}, \quad 5 \mathrm{mM} \quad \mathrm{MgSO}_{4}, \quad 5 \mathrm{mM}$ $\mathrm{Na}_{2}$ ATP, $5 \mathrm{mM}$ creatine, $20 \mathrm{mM}$ taurine, 20 $\mathrm{mM}$ glucose and $0.2 \mathrm{mM}$ EGTA ( $\mathrm{pH}$ was adjusted to 7.4). The temperature of the perfusate was kept at $37^{\circ} \mathrm{C}$ during the coronary perfusion. The right ventricle was dispersed in the storage solution with forceps, and dispersed single cells were kept in a storage solution at room temperature $\left(24-26^{\circ} \mathrm{C}\right)$ for later experiments.

\section{Electrical recording}

The sodium current $\left(\mathrm{I}_{\mathrm{Na}}\right)$ in the isolated single ventricular cells was measured by using a single suction pipette which enabled intracellular perfusion and a whole-cell clamp $(11,16)$. Experiments were carried out with viable rod-shaped myocytes using the concentration-clamp technique (17). Briefly, a single myocyte was aspirated onto the tip of a suction pipette (inner diameter of 2 to $3 \mu \mathrm{m}$ at the tip) and dialyzed intracellularly with the internal solution ( $\mathrm{pH} 7.4$ ) containing 130.0 $\mathrm{mM} \mathrm{KOH}, 130.0 \mathrm{mM}$ L-aspartate, $2.5 \mathrm{mM}$ $\mathrm{KH}_{2} \mathrm{PO}_{4}, 2.0 \mathrm{mM} \mathrm{Na} \mathrm{NaTP}_{2}, 5.5 \mathrm{mM}$ glucose, $10.0 \mathrm{mM}$ HEPES and $5.0 \mathrm{mM}$ EGTA. The tip of the suction pipette with attached cell was inserted into a plastic tube through a circular hole. The lower end of this tube was directly exposed to the external Tyrode's solution ( $\mathrm{pH}$ 7.4) containing $136.5 \mathrm{mM} \mathrm{NaCl}, 5.4 \mathrm{mM} \mathrm{KCl}$, $1.8 \mathrm{mM} \mathrm{CaCl}, \quad 0.53 \mathrm{mM} \mathrm{MgCl}_{2}, \quad 0.33 \mathrm{mM}$ 
$\mathrm{NaH}_{2} \mathrm{PO}_{4}, 11.9 \mathrm{mM} \mathrm{NaHCO} 3,5.5 \mathrm{mM}$ glucose and $5.0 \mathrm{mM}$ HEPES. The external Tyrode's solution could be exchanged around a ventricular myocyte with a time constant of 2 msec by the negative pressure controlled by the electromagnetic valve.

The membrane potential was controlled using a single-electrode voltage-clamp circuit, switching at a frequency at $10 \mathrm{kHz}$ and passing current for $36 \%$ of the cycle. Clamp currents were measured as the voltage drop across a 10 $\mathrm{M} Q$ resistor in the feed-back loop of the head stage amplifier. In this system, the suction electrode could carry time-averaged currents exceeding $20 \mathrm{nA}$ at a switching frequency of $10 \mathrm{kHz}$ without showing signs of polarization or other artifacts. A phase-compensation feedback loop was used to stabilize the clamp circuit. The voltage clamp was turned to give the most rapid response, as follows: the holding potential was set to the resting potential, the gain was gradually increased and the compensation circuit was adjusted. As the gain reached a maximum level, the circuit was adjusted until the voltage trace was critically clamped. I $\mathrm{Na}_{\mathrm{a}}$ was elicited by the depolarizing pulse with $20-\mathrm{msec}$ duration from a holding potential of $-80 \mathrm{mV}$ to $-20 \mathrm{mV}$, at various intervals. All $\mathrm{I}_{\mathrm{Na}}$ measurements were performed at room temperature $\left(24-26^{\circ} \mathrm{C}\right)$.

The amplitude of $\mathrm{I}_{\mathrm{Na}}$ was estimated as the maximal peak $\mathrm{I}_{\mathrm{Na}}$ from the steady background current at the end of the step. To study the rate-dependent inhibition, the trains of depolarizing clamp pulses were applied at frequencies ranging from 0.5 to $3.0 \mathrm{~Hz}$. A rest pcriod of $60 \mathrm{sec}$, which was enough to ensure full recovery from the rate-dependent decrease in $\mathrm{I}_{\mathrm{Na}}$, was interposed between the trains of stimuli. The onset rate of $\mathbf{I}_{\mathrm{Na}}$ inactivation was calculated according to the method of Campbell (18) or Courtney (19). The recovery process from inactivation of $\mathrm{I}_{\mathrm{Na}}$ was studied by using the double-pulse method. Each twopulse sequence, which consists of a $20 \mathrm{msec}$ conditioning pulse and $20 \mathrm{msec}$ test pulse with voltage step from $-80 \mathrm{mV}$ to $-20 \mathrm{mV}$, was applicd every $10 \mathrm{sec}$. The recovery time con- stant $\left(\tau_{1}, \tau_{2}\right)$ was calculated according to the method of Yatani and Akaike (7).

In case of intracellular application of pilsicainide, a single cell was dialyzed intracellularly with "internal solution" containing the drug through a suction pipette. The agent was perfused for $5 \mathrm{~min}$ to the preparation which was constantly driven at $1 \mathrm{~Hz}$. Thereafter, the preparation was driven at various frequencies with a rest period of $60 \mathrm{sec}$. In the case of extracellular application of the agent, it was added to the external Tyrode's solution and applied extracellularly by the concentrationclamp technique. The membrane current was monitored on a digital oscilloscope (National, VP-5730A) and simultaneously stored on an FM-tape recorder (Sony, A-45) for further analyses.

\section{RESULTS}

\section{Inactivation of $I_{N a}$}

The extent of inactivation of $\mathrm{I}_{\mathrm{Na}}$ was determined by applying trains of depolarizing clamp pulses from -80 to $-20 \mathrm{mV}$ for 20 -msec duration to a single myocyte, at a frequency of $\mathrm{I} \mathrm{Hz}$. The original current traces of $I_{\mathrm{Na}}$ are shown in Fig. 1.

There were observed slight notches in the decay phase of the capacitive surge of $\mathrm{I}_{\mathrm{Na}}$. Usually, successful voltage clamp of $I_{N a}$ in single myocytes was obtained in a condition of low temperature and low extracellular $\mathrm{Na}$ (20). In the present study, we conducted the experiments at room temperature and in normal extracellular $\mathrm{Na}$ concentration, which might be a cause of the apparent incomplete voltage clamp.

In the absence of pilsicainide, $\mathbf{I}_{\mathrm{Na}}$ remained fairly constant. Extracellular application of $10^{-5} \mathrm{M}$ pilsicainide caused a gradual decrease in the amplitude of $\mathrm{I}_{\mathrm{Na}}$, which then reached a new steady state level at the $10-20$ th pulses. In case of intracellular application of $10^{-3} \mathrm{M}$ pilsicainide, the amplitude of $\mathrm{I}_{\mathrm{Na}}$ decreased gradually for the first $5 \mathrm{~min}$, and no further decrease was observed thereafter, suggesting that the intracellular concentration of the drug 
A

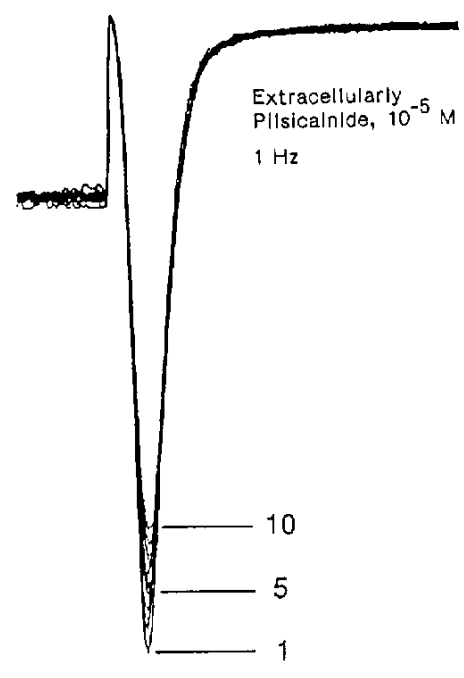

B

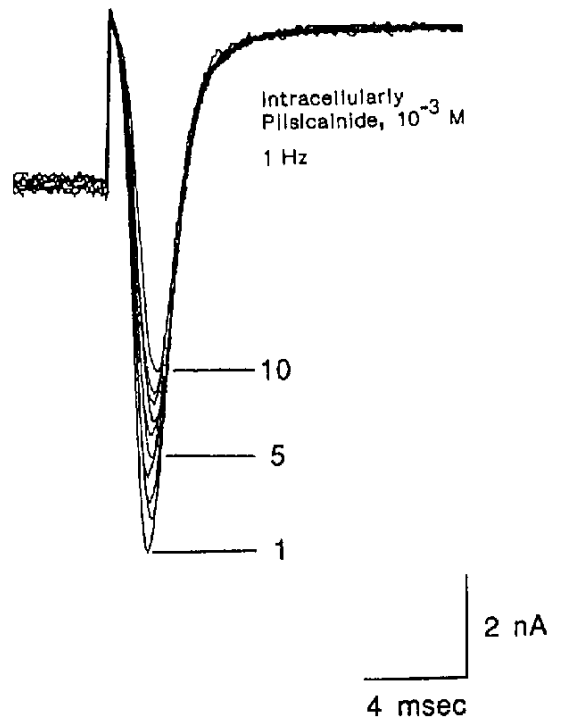

Fig. 1. Use dependent block of $I_{\mathrm{Na}}$ by extracellular (A) or intraccllular (B) application of pilsicainide. The original current traces elicited by depolarizing pulses from -80 to $-20 \mathrm{mV}$ for 20 -msec duration at the frequency of $1 \mathrm{~Hz}$ were superimposed. Each number shown at the right side of the current traces indicates the number of depolarization after a quiescent periods of $60 \mathrm{sec}$. Panel $\mathrm{A}$ : In the presence of $10^{-5} \mathrm{M}$ pilsicainide in extracellular solution. Panel B: In the presence of $10^{-3} \mathrm{M}$ pilsicainide in intracellular solution.

reached an equilibrium within $5 \mathrm{~min}$. After confirming that the $I_{\mathrm{Na}}$ reached a steady state, the preparation was driven at $1 \mathrm{~Hz}$ after a quiescent period of $60 \mathrm{sec}$. The amplitude of $\mathrm{I}_{\mathrm{Na}}$ gradually decreased in a use-dependent manner. In the cells intracellularly loaded with $10^{-4} \mathrm{M}$ pilsicainide, no measurable decrease in $\mathrm{I}_{\mathrm{Na}}$ was observed. However, $\mathrm{I}_{\mathrm{Na}}$ was decreased in a use-dependent manner following the additional extracellular application of $10^{-5}$ $M$ pilsicainide in the same cells. These results suggest that $\mathrm{I}_{\mathrm{Na}}$ use-dependently decreases in the presence of either intracellular or extracellular pilsicainide.

\section{Rate dependent block of $I_{N a}$}

In the absence of the drug, $\mathrm{I}_{\mathrm{Na}}$ remained fairly constant at any pulse frequency. In the presence of extracellular $10^{-5} \mathrm{M}$ pilsicainide, the amplitude of $\mathbf{I}_{\mathrm{Na}}$ decreased, reaching a new steady state level in a frequency-depend- ent manner (Fig. 2). No measurable blocking action of pilsicainide was observed at the concentration of $10^{-6} \mathrm{M}$, and complcte inhibition of $\mathbf{I}_{\mathrm{Na}}$ was induced by $10{ }^{4} \mathrm{M}$ pilsicainide within a few pulses given at any frequency. A similar reduction of $\mathrm{I}_{\mathrm{Na}}$ was elicited in the cells loaded with $10^{-3} \mathrm{M}$ pilsicainide intracellularly. These results imply that a block of $\mathrm{I}_{\mathrm{Na}}$ by either externally or internally applied pilsicainide increases proportionally to the increase of the rate of stimulation; and is therefore a rate-dependent block.

\section{Effect on onset rate of $I_{N a}$ inactivation}

Figure 3 illustrates the changes in peak amplitude of $\mathrm{I}_{\mathrm{Na}}$ during a train of stimuli at various frequencies in the presence of (extracellular, Fig. 3A or intracellular, Fig. 3B) pilsicainide. The development of the use-dependent block of $I_{\mathrm{Na}}$ is well-characterized as a single exponential process versus the number 
of applied pulses $(18,19)$. In cells loaded with internal $10^{-3} \mathrm{M}$ pilsicainide, the onset rate of decline in $\mathrm{I}_{\mathrm{Na}}$ was relatively constant (0.098 to

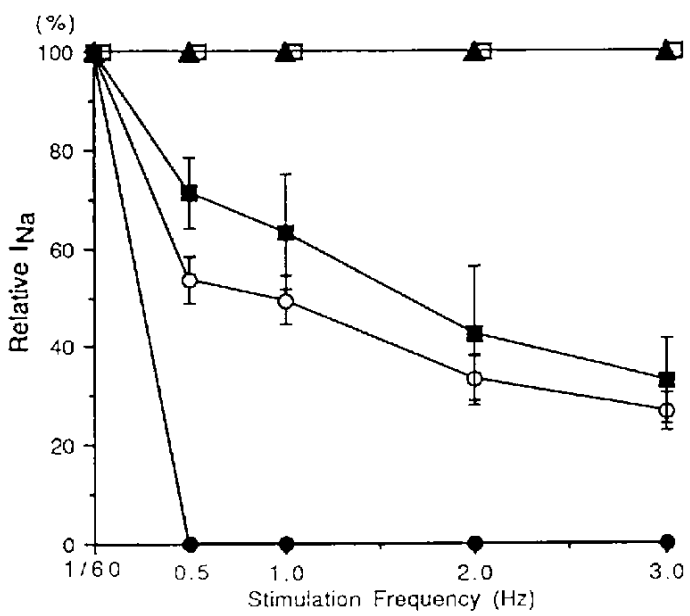

Fig. 2. Rate-dependent block of $\mathrm{I}_{\mathrm{Na}}$ by extracellular or intracellular applications of pilsicainide. Each symbol indicates the mean of $\mathrm{I}_{\mathrm{Na}} \pm \mathrm{S}$.E. (percentage of control) at steady-state level following treatment with pilsicainide extracellularly $\left(\boldsymbol{\Delta} 10^{6} \mathrm{M}, \mathrm{N}=2 ; \mathbf{D} 10^{-5}\right.$ $\mathrm{M}, \mathrm{N}=3 ; 010^{-4} \mathrm{M}, \mathrm{N}=3$ ) or intracellularly ( $\square$ $\left.10^{4} \mathrm{M}, \mathrm{N}=3 ; \bigcirc 10^{-3} \mathrm{M}, \mathrm{N}=4\right)$. Values werc normalized for the first $I_{N a}$ elicited after a quiescent period of $60 \mathrm{sec}$.

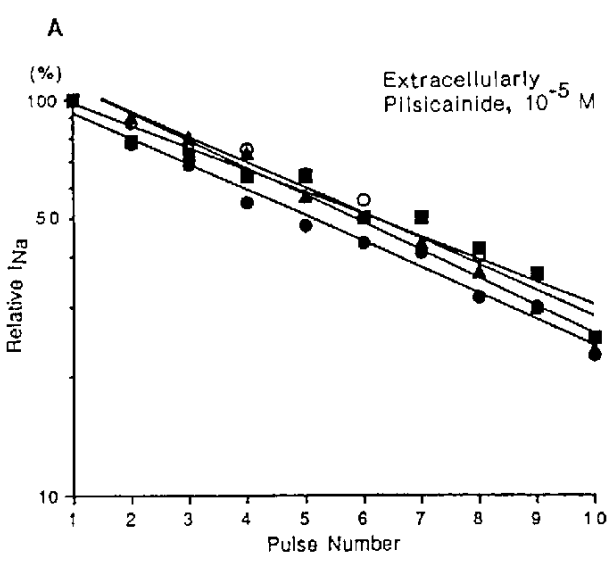

0.130 per pulse) regardless of stimulus frequency (Table 1). Similar results were obtained when pilsicainide was applied extracellularly (Table 1). The onset rate of $I_{\mathrm{Na}}$ inactivation was not dependent on frequency at a given concentration of pilsicainide, but was larger at the highest concentration tested (Table 1). It was about 0.10 per pulse and 0.45 per pulse in the presence of extracellular $10^{-5} \mathrm{M}$ and $10^{-4} \mathrm{M}$ pilsicainide, respectively. Thus, on both intracellular and extracellular applications of the drug, the onset rate of $I_{\mathrm{Na}}$ inactivation was independent of the frequency of stimulus.

\section{Effects on recovery rate from $I_{N a}$ inactivation}

$\mathrm{I}_{\mathrm{Na}}$ (test) / $\mathrm{I}_{\mathrm{Na}}$ (conditioning) or $\mathrm{It} / \mathrm{Ic}$ was plotted against the pulse interval (the recovery curve) in the absence (control) and in the presence of extracellular $\left(10^{-5} \mathrm{M}\right)$ and intracellular $\left(10^{-3} \mathrm{M}\right)$ pilsicainide (Fig. 4A). A logarithmic scale of $1-\mathrm{It} / \mathrm{Ic}$ was also plotted against the pulse interval (Fig. 4B).

In the absence of the drug, the recovery curve was fitted by a single exponential with a time constant $\left(\tau_{\mathrm{r}}\right)$ of $14.0 \mathrm{msec}$ (Table 2). In the presence of $10^{-3} \mathrm{M}$ pilsicainide in the internal solution, the recovery curve was fitted

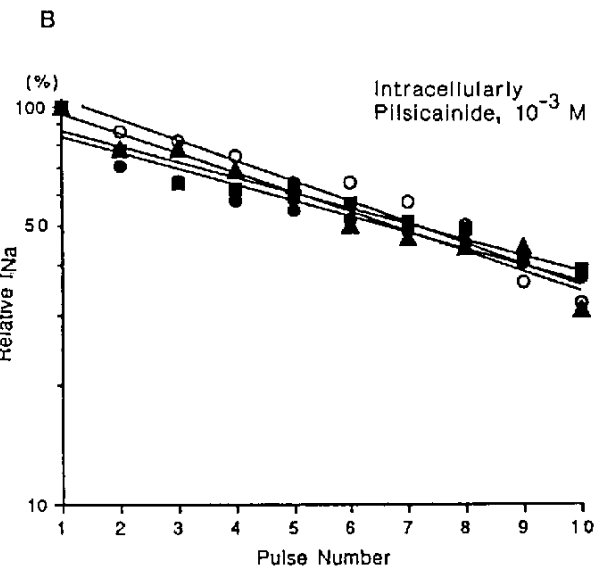

Fig. 3. Effect of external (A) or internal (B) applicution of pilsicainide on the onset rate of $\mathbf{I}_{\mathrm{Na}}$ block. The logarithms of the decremental losses of $\mathrm{I}_{\mathrm{Nat}}$ during the first 10 pulses in the train were plotted against the pulse number. The depolarizing pulses were applied at $\bigcirc 0.5 \mathrm{~Hz}, \Delta 1 \mathrm{~Hz}, \square 2 \mathrm{~Hz}, \bigcirc \mathrm{Hz}$. 
Table 1. Onset rates of rate-dependent block of $I_{\mathrm{Na}}$ by pilsicainide applicd intracellulary or extracellularly

\begin{tabular}{|c|c|c|c|}
\hline & \multirow{2}{*}{$\frac{\text { Intracellularly }}{\text { Pilsicainide, } 10^{-3} \mathrm{M}}$} & \multicolumn{2}{|c|}{ Extracellularly } \\
\hline & & $\begin{array}{c}\text { Pilsicainide, } 10{ }^{5} \mathrm{M} \\
\mathrm{N}=3\end{array}$ & $\begin{array}{c}\text { Pilsicainide, } 10^{-4} \mathrm{M} \\
\mathrm{N}=3\end{array}$ \\
\hline $0.5 \mathrm{~Hz}$ & $0.098 \pm 0.008 /$ pulse & $0.087 \pm 0.006 /$ pulse & $0.477 \pm 0.195 /$ pulse \\
\hline $1.0 \mathrm{~Hz}$ & $0.106=0.002$ & $0.096 \_0.010$ & $0.450 \pm 0.092$ \\
\hline $2.0 \mathrm{~Hz}$ & $0.115 \pm 0.005$ & $0.123 \pm 0.038$ & $0.484 \pm 0.089$ \\
\hline $3.0 \mathrm{~Hz}$ & $0.130(\mathrm{~N}=2)$ & $0.097 \pm 0.008$ & $0.434 \pm 0.075$ \\
\hline
\end{tabular}

Each value represents mean \pm S.E.
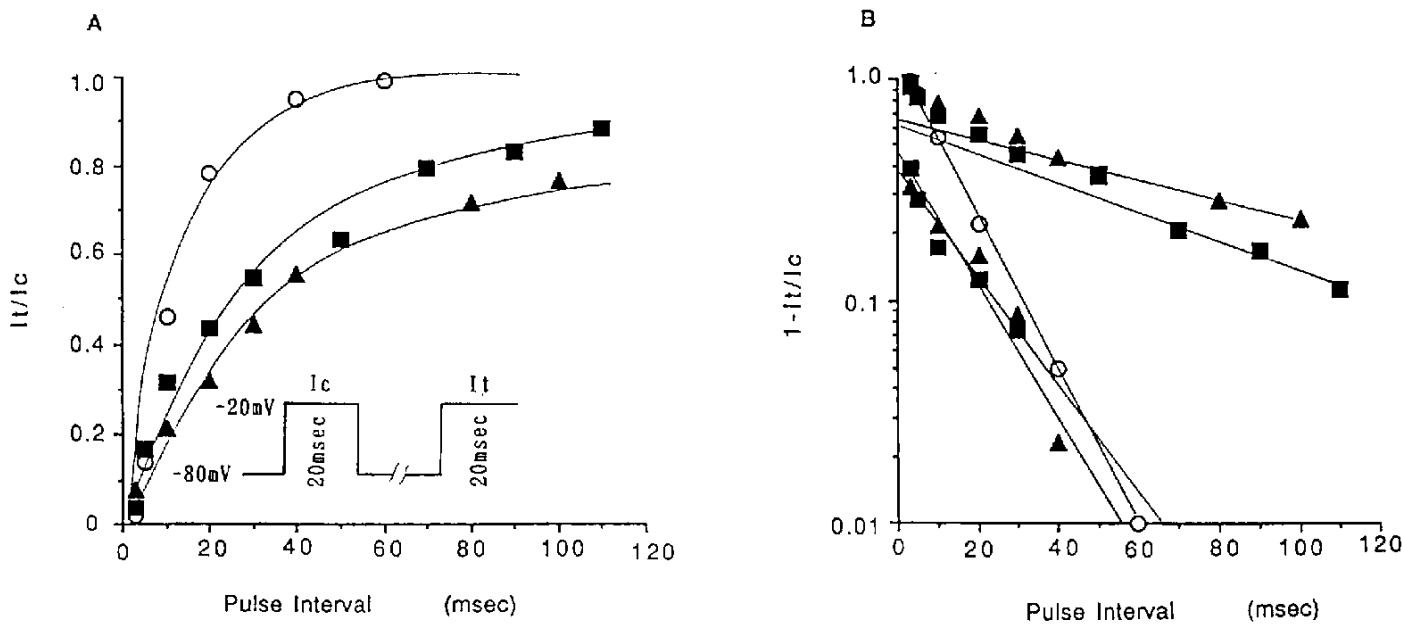

Fig. 4. Effects of intracellular or extracellular application of pilsicainide on the recovery of $\mathbf{I}_{\mathrm{Na}}$ from inactivation. $\mathrm{I}_{\mathrm{Na}}$ was evoked by a test pulsc (Jt) at various intervals after a conditioning pulse (Ic). Panel A: Time course of recovery of $I_{\mathrm{Na}}$. Inset is the double pulse program. $I_{\mathrm{Na}}$ was evoked by a test pulse (It) at varying intervals after a conditioning pulse (Ic). Panel B: Same data as in A, but plotted semilogarithmically. $\bigcirc$ control; $\square$ intracellularly applied pilsicainide $10^{-3} \mathrm{M} ; \boldsymbol{\Delta}$ extracellularly applied pilsicainide, $10^{-5} \mathrm{M}$.

Table 2. Effect of pilsicainide applied intraccllularly or extracellularly on the time constant for the recovery of $\mathrm{I}_{\mathrm{Na}}$ from inactivation

\begin{tabular}{|c|c|c|c|c|}
\hline & \multirow{2}{*}{$\begin{array}{l}\text { Control } \\
\mathrm{N}=7\end{array}$} & Intracellularly & \multicolumn{2}{|c|}{ Extracellularly } \\
\hline & & $\begin{array}{c}\text { Pilsicainide, } 10^{3} \mathrm{M} \\
\mathrm{N}=4\end{array}$ & $\begin{array}{c}\text { Pilsicainide, } 10^{-5} \mathrm{M} \\
\mathrm{N}=3\end{array}$ & $\begin{array}{c}\text { Pilsicainide, } 10^{4} \mathrm{M} \\
\mathrm{N}=2\end{array}$ \\
\hline $\begin{array}{l}\tau_{r} \\
\text { (msec) }\end{array}$ & $14.0 \pm 1.9$ & $\begin{array}{l}\tau_{1} \\
(\text { msec) } 17.5 \pm 2.7 \\
\tau_{2} \\
(\operatorname{msec}) 77.0 \pm 9.5\end{array}$ & $\begin{array}{l}15.0 \pm 3.8 \\
64.7 \pm 12.2\end{array}$ & - \\
\hline
\end{tabular}

Each value represents mean \pm S.E. 
by two exponentials, with a first phase $\left(\tau_{1}=\right.$ $17.5 \mathrm{msec})$ and a second phase $\left(\tau_{2}=77\right.$ msec). The $\tau_{1}$ was close to the $\tau_{\mathrm{r}}$. Similar results were obtained in the extracellular application of $10{ }^{5} \mathrm{M}$ pilsicainide. The $\tau_{1}$ (15.0) msec) was almost equal to that $(17.5 \mathrm{msec})$ in the cclls loaded with internal pilsicainide. In addition, the $\tau_{2}(64.7 \mathrm{mscc})$ was almost similar to that $(77.0 \mathrm{msec})$ in internally loaded cells. When $10^{-4} \mathrm{M}$ pilsicainide was applied externally, the recovery curve was fitted by a single exponential with a slower phase. Thus, the recovery of $I_{N_{a}}$ from inactivation was delayed in a similar manner in both cases of intracellular and extracellular pilsicainide.

\section{DISCUSSION}

In the present experiment, we assessed the $\mathrm{I}_{\mathrm{Na}}$-inhibitory action of pilsicainide, a newly developed antiarrhythmic agent of the class Ic type, applicd to a single cardiac myocyte intracellularly and cxtracellularly. Pilsicainide blocked $\mathrm{Na}$ current in use- and rate-dependent manners, when it was applied either intracellularly or extracellularly. In regard to the approach of an antiarrhythmic agent to the binding site, its mode of action and kinetics are modulated not only by the molecular form of the drug but also by whether the drug is in the charged or neutral form, which is determined by the pKa of the drug and the $\mathrm{pH}$ of the external solution and cytoplasm (1). Penticainide exists as the charged form at physiological $\mathrm{pH}(\mathrm{pKa}=10.0)$ and shows a very low lipophilicity (partition coefficient $=0.35$ ) (4), and these characteristics are similar to those of pilsicainide ( $\mathrm{pKa}=10.5$ and partition coefficient $=1.73$ at $\mathrm{pH} 7.0)(13,14)$. Therefore, it is expected that the mode of action of pilsicainide is similar to that of penticainide. Recently, Gruber et al. (5) revealed that penticainide blocked the $\mathrm{Na}$ channels of cardiac myocytes by acting from the outside as well as from the cytoplasmic side. This finding and our results might support a hypotheses that charged form antiarrhythmic agents are accessible to their binding site from the out- side as well as the inside.

In neuronal cells, the quaternary derivatives of lidocaine, which exist as charged molecules at physiological $\mathrm{pH}$, blocked $\mathrm{Na}$ channels only from the inside (2). This result does not coincide with the finding obtained by Carmeliet et al. (4) and by ourselves in cardiac myocytes. While it has been believed that Na channels have the same functional and structural profile in neuronal and cardiac cells, recent molecular biological approaches revealed the existence of subtypes of $\mathrm{Na}$ channels in neuronal and cardiac cells. In these $\mathrm{Na}$ channel subtypes, there was found low homology at the cytoplasmic and extracellular region but high homology at the penetrating region of the cell membrane $(21,22)$. Therefore, the functional profile of $\mathrm{Na}$ channels might be different in neuronal and cardiac cells. Our results also support this possibility.

Recently, Alpert et al. (6) reported that QX-314, a permanently charged analogue of lidocaine, blocked $I_{\mathrm{Na}}$ when applied not only from the inside, but also from the outside. On the basis of these observations, they postulated that there are two binding sites for local anesthetics in the heart muscle cell, one inside and another outside of the cell. In the present experiment, pilsicainide reduced $\mathrm{I}_{\mathrm{Na}}$ in usc- and rate-dependent manners, when applied intracellularly or extracellularly. The features of the block by the intracellular application of pilsicainide were almost identical to those induced by the extracellular application. Our results raise a possibility that there is a single binding site for pilsicainide and the drug reaches to the binding sitc either from outside or from inside of the cell membrane in the $\mathrm{Na}$ channel. To further verify the pilsicainide binding site, we analyzed the effects of the intracellularly or extracellularly applied pilsicainide on the onset rate of blockade of and recovery from inactivation of $\mathbf{I}_{\mathrm{Na}}$. The onset rate of $\mathbf{I}_{\mathrm{Na}}$ blockade, which reflects the rate of pilsicainide binding to the specific binding site in Na channels, was essentially constant at any stimulus frequency irrespective of different routes of application. The rate of recovery 
from the inactivation of $\mathrm{I}_{\mathrm{Na}}$, which represents the rate of dissociation of pilsicainide from the binding site, was almost consistent in both cases of the drug applications and was constant in the drug concentration range used in this study. These results suggest that pilsicainide, when applied inside or outside the cell, shares a common binding site to block the Na current.

When pilsicainide was applied intracellularly, a concentration about 100 -fold that required in extracellular application was necessary to obtain a similar blocking action. The result may suggest that pilsicainide is more easily accessible to its binding site from the outer side of the membrane than from the inner side, as suggested by Gruber et al. (5) for penticainide. However, in the present experiments, the intracellular concentration of pilsicainide was not determined since the drug was applied intracellularly by simple diffusion through the recording suction pipette. Accordingly, further experiments with use of an inside-out patch technique are necessary to confirm this assumption.

In conclusion, it is clear that pilsicainide internally applied from the recording pipette blocks $\mathrm{I}_{\mathrm{Na}}$ in cardiac myocytes with kinetics very similar to those of the drug applied externally. The result suggests that pilsicainide, a charged-form antiarrhythmic agent, is accessible to its binding site either from the outer side or from the inner side of the cardiac cell membrane, and that it shares a common binding site to block $\mathrm{I}_{\mathrm{Na}}$.

\section{Acknowledgments}

The authors wish to thank Drs. M. Morita, T, Ishihara and $\mathrm{Y}$. Imaizumi for their helpful suggestions on the manuscript and Dr. T. Noguchi, the Director of the Suntory Institute for Biomedical Research, for his support and encouragement throughout this study.

\section{REFERENCES}

1 Hille, B.: The pH-dependent rate of action of local anesthetics on the node of ranvier. J. Gen. Physiol. 69, 475-496 (1977)

2 Hille, B.: Local anesthetics: Hydrophobic and hydrophilic pathways for the drug-receptor interaction. J. Gen. Physiol. 69, 497-515 (1977)

3 Courtney, K.R.: Mechanism of frequency-dependent inhibition of sodium currents in frog myelinated nerve by the lidocaine derivative GEA968. J. Pharmacol. Exp. Ther. 195, 225-236 (1975)

4 Carmeliet, E., Nilius, B. and Vereecke, J.: Properties of the block of single $\mathrm{Na}$ channels in guineapig ventricular myocytes by the local anaesthetic penticainide. J. Physiol. (Lond.) 409, 241-262 (1989)

5 Gruber, R., Vereecke, J. and Carmelict, E.: Dual effect of the local anaesthetic penticainide on the $\mathrm{Na}$ current of guinea-pig ventricular myocytes. $\mathbf{J}$. Physiol. (Lond.) 435, 65-81 (1991)

6 Alpert, L.A., Fozzard, H.A., Hanck, D.A. and Makielski, J.C.: Is therc a second external lidocaine binding site on mammalian cardiac cells? Am. J. Physiol, 257, H79-H84 (1989)

7 Yatani, A. and Akaike, N.: Effects of a new antiarrhythmic compound SUN $1165 \quad[N-(2,6-$ dimethylphenyl)-8-pyrrolizidineacetamide] hydrochloride on the sodium currents in isolated single rat ventricular cells. Naunyn Schmiedebergs Arch. Pharmacol. 326, 163 - 168 (1984)

8 Hattori, Y., Inomata, N., Aisaka, K. and Ishihara, T.: Electrophysiological actions of $N$ (2,6-dimethylphenyl)-8-pyrrolizidine-acetamide hydrochloride hemihydrate (SUN 1165), a new antiarrhythmic agent. J. Cardiovasc. Pharmacol. 8, $998-1002(1986)$

9 Inomata, N., Ishihara, T. and Akrike, N.: SUN 1165: a new antiarrhythmic Na current blocker in ventricular myocytes of guinea-pig. Comp. Biochem. Physiol. [C] 87C, 237-243 (1987)

10 Hattori, Y., Hidaka, T., Aisaka, K., Satoh, F. and Ishihara, T.: Effect of SUN 1165, a new potent antiarrhythmic agent, on the kinetics of ratedependent block of $\mathrm{Na}$ channels and ventricular conduction of extrasystoles. J. Cardiovasc. Pharmacol. 11, 407-412 (1988)

11 Inomata, N., Ishihara, T, and Akaike, N.: Different time courses of the blockade of sodium current by lignocaine and SUN 1165 in single myocytes isolated from guinea-pig atrium. Br. J. Pharmacol. 98, 149-154 (1989)

12 Aisaka, K., Hidaka, T., Inomata, N., Hamasaki, S., Ishihara, T. and Morita, M.: N-(2,6-Dimethylphenyl)-8-pyrrolizidineacetamide hydrochloride hemihydrate (SUN 1165): A new potent and longacting antiarrhythmic agent. Arzneimittelforschung $35,1239-1245$ (1985)

13 Miyano, S., Sumoto, K., Satoh, F., Shima, K., Hayashimatsu, M., Morita, M. et al.: New anti- 
arrhythmic agents, $N$-aryl-8-pyrrolizidinealkanamides. J. Med. Chem. 28, 714-717 (1985)

14 Toyama, J., Kodama, I., Kusunoki, T., Ishihara, T., Hattori, Y. and Yamada, K.: Use-dependent blocking action of newly developed lidocaine-analogs on maximum rate of rise of action potentials in guinea pig papillary muscle. Japan. Circ. J. 28, $273-285$ (1987)

15 Matsuda, H., Noma, A., Kurachi, Y. and Irisawa, H.: Transient depolarization and spontancous voltage fluctuations in isolated single cells from guinca-pig ventricles. Calcium-mediated membrane potential fluctuations. Circ. Res. 51, 142-151 (1982)

16 Akaike, N., Inomata, N. and Tokutomi, N.: Contribution of chloride shifts to the fade of gammaaminobutyric acid-gated currents in frog dorsal root ganglion cells. J. Physiol. (Lond.) 391, $219-$ 234 (1987)

17 Akaike, N., Inoue, $\mathrm{N}$ and Krishtal, A.: "Concentration-clamp" study of gamma-aminobutyric acid-induced chloride current kinetics in frog sensory neurones. J. Physiol. (Lond.) 379,
$171-185$ (1986)

18 Camphell, T.J.: Importance of physico-chemical properties in determining the kinetics of the effects of class I antiarrhythmic drugs on maximum rate of depolarization in guinea pig ventricle. Br. J. Pharmacol. 80, 33-40 (1983)

19 Courtney, K.R.: Fast frequency-dependent block of action potential upstroke in rabbit atrium by small local anesthetics. Life Sci. 24, 1581-1588 (1979)

20 Brown, A.M., Lee, K.S. and Powell, T.: Sodium currents in single rat heart muscle cells. J. Physiol. (Lond.) 318, $479-500$ (1981)

21 Noda, M., Ikeda, T., Kayano, T., Suzuki, H., Takashima, H., Kurasaki, M. et al.: Existence of distinct sodium channel messenger RNAs in rat brain. Nature 320, 188- 192 (1986)

22 Rogart, R.B., Cribbs, L.L., Muglia, L.K., Kephart, D.D. and Kaiser, M.W.: Molecular cloning of a putative tetrodotoxin-resistant rat heart Na channel isoform. Proc. Natl. Acad. Sci. U.S.A. 86, $8170-8174$ (1989) 